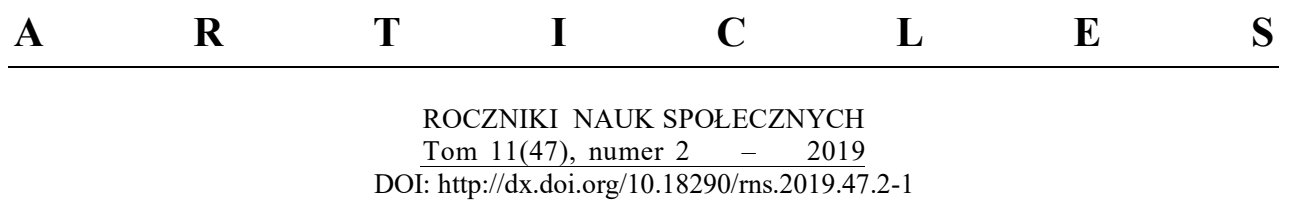

AUGUSTĖ DEMENTAVIČIENĖ

\title{
A POLITICAL ACT IN THE E-SOCIETY: DIGITAL VIGILANTISM AND SWARMS
}

\section{INTRODUCTION $^{1}$}

New technologies are rapidly transforming everyday life in almost every corner of our planet. The sheer rapidity of this process causes that they are provoking more and more debates in the public sphere. They also give rise to new paradoxes, for example, in such cases as human body enhancements or modifications, transgender athletes or the use of stem cells in research, which has become even part of political discussions. In addition to that, questions about virtualization, gamification, cybersecurity, big data are also creating a lot of new space for debate on a political level. The new technologies have become a dynamic site of interest across various disciplinary boundaries and the changes will inevitably affect the concept of what is political and what could or could not be done politically.

The case of digital vigilantism (DV), analysed in this article, is considered to be one of the best examples for exploring the technological change and transformations it causes. The main idea here is to contribute to

Augusté DementavičIenEe, a PhD candidate and a research assistant at the Department of Political Philosophy and History of Ideas, Institute of International Relations and Political Science, Vilnius University; address for correspondence: Vokiečių gatve, 10-306 Vilnius, Lithuania; e-mail: auguste.dementaviciene@tspmi.vu.lt.

${ }^{1}$ This paper is a follow-up to the presentation I delivered during the 19th International Scientific Conference "New Problems of E-economy and E-society," held in Nałęczów, Poland, on May 21-23, 2018, titled "Political Act in the E-society: The Case of Digital Vigilantism." Also, this article is part of a bigger project, and some chapters of this paper are taken from A. DEMENTAVIČIENĖ, "Kaip naujosios technologijos nulemia politinio veiksmo suvokimą: Digital Vigilantism atvejis?” Politologija 95, no. 3 (2019): 33-55. 
the discussion of processes that we know will have significant repercussions, while at the same time not knowing what specifically those changes will bring, which in this case is in the realm of politics. As a result, a philosophical approach will be employed for our analysis in order to explore the postmodern concepts of a political act, including the contexts in which they develop.

One of the main issues addressed by the article is the change in the attitude to the Internet as a new and radically empowering platform for democracy, which was so widespread in the 1990s (we remember John Perry Barlow's almost-utopian "A Declaration of the Independence of Cyberspace" from 1996) and the early 2000s. Currently, our realization of the more negative influence that the Internet and digital platforms may have on society and politics is quite alarming. The latter topic also gives a headache to legal experts and scholars - how can one impose a legal regulation on something that is based on freedom and anonymity at its core?

So, on the one hand, the technological question is inevitable, but on the other there are some major problems that make these questions hard to reflect on philosophically. Firstly, the technological language is often hermetic as used by the field professionals, which makes it harder for politicians, philosophers and social scientists to follow. Secondly, the conceptual instruments that are being used in their current forms prove to be insufficient for interpreting and elucidating the current processes at play. This need for new ideas, tools, and approaches causes a certain "empirical turn,"2 after which even philosophers are paying more and more attention, trying to grapple with new scientific and technological developments.

The main aim of this article is to introduce the question of new political forms spreading because of the new technological instruments, which are easily available for everybody. Also, I am trying to reinterpret Zygmunt Bauman's idea of swarms. He introduces this idea in his book "Consuming life." The idea behind the book was to criticize and show the side effects of postmodern lifestyle and culture. For Bauman, one of the most disturbing problems of postmodernity is the vanishing culture of communities. Instead of them, as he says figuratively, swarms are born: "in a liquid modern society of consumers, the swarm tends to replace the group - with its leaders, hierarchy of authority and pecking order." 3,4 A swarm can do without all those

\footnotetext{
2 P. BReY, "Philosophy of Technology after the Empirical Turn," Techné: Research in Philosophy and Technology 14, no.1 (2010): 36-48.

${ }^{3}$ Z. Bauman, Consuming Life (Cambridge: Polity Press, 2007), 76.
} 
attributes and strategies without which a group could neither form nor be sustained. "Swarms need not be burdened by the tools of survival; they assemble, disperse and gather again, from one occasion to another, each time guided by different, invariably shifting relevancies, and attracted by changing and moving targets." I found the metaphor of swarms quite intriguing and had an idea that it could be suitable for the the analysis of a specific example of e-society (digital vigilantism). However, I found it very odd that in this book Bauman almost neglects the existence of Michel Foucault's ideas. My idea was to add the changes that biopower includes in the modern and postmodern understanding of the politics.

The focus of media and academic research on digital or online vigilantism has been on the rise over the last decade ${ }^{6,7}$ Nevertheless, it is still quite a new phenomenon and requires special attention because of its complexity and effects on different fields. ${ }^{8}$ It goes back to the discussion on whether technology itself is a neutral tool or not. ${ }^{9}$ The approach of this article is that technology is not fully neutral, despite appearing so, and that movements and changes are dependent on the features of social media and other platforms.$^{10}$ There are a great many articles analyzing this phenomenon from the perspective of media studies ${ }^{11,12,13}$ or from a legal perspective. ${ }^{14}$ In addition,

${ }^{4}$ The author of this article is fully aware that Bauman's understanding of insect swarms or animal behavior patterns is quite limited. The metaphors and conclusions sometimes contradict the evidence gathered in life sciences. Bauman uses a simplified, stereotypical, and even negative understanding of swarms in order to put greater emphasis on its difference from the community. For some examples of studies on bee swarms, see H. KwONG and Ch. JACOB, "Evolutionary Exploration of Dynamic Swarm Behaviour" (paper presented at the 2003 Congress on Evolutionary Computation, Canberra, Australia, December 8-12, 2003), IEEE (May 24, 2004), doi:10.1109/ CEC.2003.1299599; M. KUDĚLKA ET AL., "Social and Swarm Aspects of Co-authorship Network," Logic Journal of the IGPL 20, no. 3 (2012): 634-43

${ }^{5}$ Bauman, Consuming Life, 76.

${ }^{6}$ J. Smallridge, P. Wagner, and J.N. Crowl, "Understanding Cyber-Vigilantism: A Conceptual Framework," Journal of Theoretical \& Philosophical Criminology 8, no. 1 (2016): 58.

${ }^{7}$ B. Loveluck, "The Many Shades of Digital Vigilantism. A Typology of Online SelfJustice," Global Crime (June 4, 2019): 1-29.

${ }^{8}$ S. TANner and A. CAmpana, “'Watchful Citizens' and Digital Vigilantism: A Case Study of the Far Right in Quebec," Global Crime (April 26, 2019): 1-21, https://doi.org/10.1080/ 17440572.2019.1609177.

${ }^{9}$ N. Balabanian, "On the Presumed Neutrality of Technology," IEEE Technology and Society Magazine 25, no. 4 (2006): 15-25.

${ }^{10}$ For more on platformization, see J. VAN DiJCK, “'You have one identity': Performing the Self on Facebook and LinkedIn," Media, Culture \& Society 35, no. 2 (2013): 199-215.

${ }^{11}$ D. Trottier, "Digital Vigilantism as Weaponisation of Visibility," Philosophy \& Technology 30 , no. 1 (2017): 55-72. 
it is obvious that with the increasing number of new cases more and more research is done and planned for the future.$^{15}$ However, there is still not much analysis in the field of political philosophy — and the field of political science in general.

The first part of the article aims to answer the question what digital vigilantism is and how it is conceptualized in the academic debate. The idea behind the first part is to familiarize the reader with the phenomenon of DV because it is still not very widespread term. The second part examines Bauman and Foucault's ideas and the main question of the article is answered: why and in what way DV is a political act, and what consequences this new way of being political might have.

\section{THE CONCEPT OF DIGITAL VIGILANTISM}

According to Loveluck, digital vigilantism is "direct online actions (emphasis mine) of targeted surveillance, dissuasion or punishment which tend to rely on public denunciation or an excess of unsolicited attention, and are carried out in the name of justice, order or safety." 16

The scope of digital vigilantism varies quite broadly: scambaiting, hacktivism, citizen-led cyber-stings, crowdsourced acts of vigilantism, ${ }^{17}$ and other forms. Digital vigilantism is a lynch law that has moved from reality to the virtual world and pervades it by means of a variety of digital tools, extremely important and based on social media, the Internet and various apps. DV goals are vastly different: from the will to implement social justice ${ }^{18}$ or citizen empowerment ${ }^{19}$ to personal revenge ${ }^{20}$ or propaganda. ${ }^{21}$ This includes

\footnotetext{
${ }^{12}$ M. KASRA, "Vigilantism, Public Shaming, and Social Media Hegemony: The Role of Digital-Networked Images in Humiliation and Sociopolitical Control," The Communication Review 20, no. 3 (2017): 172-88.

${ }^{13}$ P. H. Cheong and J. Gong, "Cyber Vigilantism, Transmedia Collective Intelligence, and Civic Participation," Chinese Journal of Communication 3, no. 4 (2010): 471-87.

${ }^{14}$ SMAllRidge, WAGNer, and Crowl, "Understanding Cyber-Vigilantism," 57-70.

15 Forthcoming: D. Trottier, R. Gabdulhakov, and Q. Huang, "Introducing Vigilant Audiences."

${ }^{16}$ B. Loveluck, "The Many Shades of Digital Vigilantism. A Typology of Online SelfJustice," Global Crime (June 4, 2019): 1-29, https://doi.org/10.1080/17440572.2019.1614444.

${ }^{17}$ Smallridge, Wagner, and Crowl, "Understanding Cyber-Vigilantism," 59.

${ }^{18}$ Cheong and Gong, "Cyber Vigilantism," 471-87.

${ }^{19}$ Smallridge, Wagner, and Crowl, "Understanding Cyber-Vigilantism," 57-70.

${ }^{20}$ R. ANDREws, "Baiters Teach Scammers a Lesson," Wired, April 8, 2006, https://www.wired. com/2006/08/baiters-teach-scammers-a-lesson.
} 
boredom or personal satisfaction with learning new hacking skills, which is a very important aspect of DV. To summarize, DV could serve as a way to empower citizens but also as an antidemocratic mechanism for normalizing the coercion of raw power, which could be dangerous. In addition, understanding of social justice varies extremely among DV groups. Nevertheless, the relation with the law is problematic in every approach described above.

Vigilantism and vigilantes have always given rise to scandal and attracted a lot of media and public attention. A number of scholars have sought to look into why vigilantism is so varied and, in a way, so confusing. There are many discussions in academic circles on how to describe vigilantism and pinpoint the scope of its acts but - typically for such discussions, they never cease. Nevertheless, in this article I will use the classical definition of vigilantism ${ }^{22}$ formulated by Les Johnston, which comes from the domain of criminological studies and is quite straighforward. It will therefore be used as a starting point for our discussion so that we understand the chief aspects of vigilantism: "A social movement giving rise to premediated acts of force - or threatened force - by autonomous citizens." ${ }^{23}$ The act of vigilantism has to include six elements for it to be regarded as conventional: planning, private agency, autonomous citizenship, use of force, reaction to crime/ deviance, and personal and collective security. However, these elements accurately describe conventional vigilantism, but they are really problematic if we attempt to understand DV.

More specifically, Table 1 below, taken from an article by Daniel Trottier, shows how the concept has evolved from conventional to digital.

Table 1. D. Trottier's key features of conventional and digital vigilantism

\begin{tabular}{|c|c|c|}
\hline & $\begin{array}{c}\text { Conventional vigilantism } \\
\text { (Johnston 1996) }\end{array}$ & Digital vigilantism \\
\hline Planning & Premeditation & Facilitated spontaneity \\
\hline Private agency & $\begin{array}{c}\text { Distinguished from state } \\
\text { and corporate actors }\end{array}$ & $\begin{array}{c}\text { Possible connections with } \\
\text { state and corporate actors }\end{array}$ \\
\hline
\end{tabular}

\footnotetext{
${ }^{21}$ KASRA, "Vigilantism, Public Shaming," 172-88.

${ }^{22}$ Smallridge, Wagner, and Crowl, "Understanding Cyber-Vigilantism," 57.

${ }^{23}$ L. Johnston, "What Is Vigilantism?" The British Journal of Criminology 36, no. 2 (1996): 220-36.
} 


\begin{tabular}{|c|c|c|}
\hline & $\begin{array}{c}\text { Conventional vigilantism } \\
\text { (Johnston 1996) }\end{array}$ & Digital vigilantism \\
\hline $\begin{array}{c}\text { Autonomous } \\
\text { citizenship }\end{array}$ & Self-protection & Asserting new boundaries \\
\hline Use of force & Embodied & Visibility as weapon \\
\hline $\begin{array}{c}\text { Reaction to } \\
\text { crime/deviance }\end{array}$ & Threat of established order & $\begin{array}{c}\text { Fusion of local and } \\
\text { mediated norms }\end{array}$ \\
\hline $\begin{array}{c}\text { Personal and } \\
\text { collective security }\end{array}$ & Policing localised territory & Mediated policing \\
\hline
\end{tabular}

Source: D. Trottier, "Digital vigilantism as weaponisation of visibility," Philosophy \& Technology 30, no. 1 (2017): 55-72.

Clearly, there are changes in all dimensions and even other different dimensions could be added. The main change is that it went from planning and premeditation to very reactive and spontaneous action. It is also obvious that the understanding of what is painful and hurtful has changed. Nowadays, the real force sometimes is not needed, but the negative visibility, negative records on the Internet could have very serious consequences in real life. ${ }^{24}$

One of the most important things and changes is that an ordinary perpetrator can be targeted by a DV "attack" - one that is unexpected and quite similar in scope with all others, for instance, inappropriate behaviour in public, ${ }^{25}$ improper choice of words when speaking about disaster victims, ${ }^{26}$ or organizers of a terrorist attack ${ }^{27}$ or government officials who abused their authority. ${ }^{28}$ The vigilance itself can be very diverse, ranging from public shaming, which often results in getting the subject fired from their job, to publishing

24 Ibid., 55-72.

25 B. Clune, "Digital Vigilantism Think Before Putting Pictures of Wrongdoing Online," The Guardian, November 29, 2013, https://www.theguardian.com/commentisfree/2013/nov/29/digital -vigilantism-think-before-pictures-of-wrongdoing-online, 2013.

${ }^{26}$ I. Fortey, "9 Awesome Cases of Internet Vigilantism,” Cracked, March 23, 2009, http:// www.cracked.com/article_17170_8-awesome-cases-internet-vigilantism.html, 2018.

${ }^{27}$ C. Hill, "How Digital Communities Cope: Cyber-vigilantism Following the Boston Marathon Bombings," The Yale Review of International Studies (April 2017), http://yris.yira.org/ essays/2039.

${ }^{28} \mathrm{KEY}$, "Sue me if you dare, my dad is Li Gang", Chinahush, October 21, 2010, http:// www.chinahush.com/2010/10/21/sue-me-if-you-dare-my-dad-is-li-gang/, 2010. 
all personal information (including that of his or her friends and family): name, surname, workplace, position, university, phone number, email, address, blood type, passwords, specific location, CCTV recordings and everything else that can be "pulled out" from the Internet.

In addition, DV, unlike a conventional action, is no longer restricted to one nation, state or village. ${ }^{29,30}$ This is due to two things. On the one hand, the principle makes it easy to remove boundaries and helps to be remotely involved in certain distant issues; one of the goals of social media is to help people who are scattered all around the world to get together and to eliminate the sense of distance. ${ }^{31}$ On the other hand, actions that cause repercussions are not necessarily addressed by the local jurisdictions or the legal systems. For example, scam baiting cases ${ }^{32}$ are very hard or even impossible to handle by the police, ${ }^{33}$ which gives vigilantes an even greater level of self-confidence and sense of legitimacy because they believe they are solving problems in no-man's land where there is no actual government. This is caused by issues existing in intermediate states between countries and systems.

Another key difference is that the participants of the lynch law usually manifest a strong anti-establishment rhetoric. Nevertheless, as scientists point out, the relationship of DV with the government and the police is much more complex, in some cases they actually act as helpers of the state and not as a force against it - for example, sharing information about criminals that is not necessarily obtainable by legal means. ${ }^{34}$ Therefore, vigilantes could assist the police to find the suspects on the Internet because (sic!) its regular user can have much better skills, more time, information and even technical capabilities than the state institutions. For example, there are a lot of CCTV cameras streaming online, so it is possible to watch various locations 24 hours a day. Police have neither the time and nor the resources, but the public may have them.

\footnotetext{
${ }^{29}$ M. Kucera and M. MAres, "Vigilantism during Democratic Transition," Policing and Society 25, no. 2 (2015): 170-87.

${ }^{30}$ K. Dennis, "Keeping a Close Watch - The Rise of Self-Surveillance and the Threat of Digital Exposure," The Sociological Review 56, no. 3 (2008): 347-57.

${ }^{31}$ C. Fuchs, Social Media: A Critical Introduction (London: Sage, 2017).

${ }^{32}$ ANDREws, "Baiters Teach Scammers a Lesson."

${ }^{33}$ D. Trottier, "Coming to Terms with Social Media Monitoring: Uptake and Early Assessment," Crime, Media, Culture" 11, no. 3 (2015): 317-33.

34 D. Trottier, "Digital Vigilantism as Critical Reinforcement of Law and Order," Re.Framing Activism, April 6, 2016, http://reframe.sussex.ac.uk/activistmedia/2016/04/digitalvigilantism-as-critical-reinforcement-of-law-and-order.
} 
Further, we should note that sometimes digital vigilantism works as a gun or instrument for state authorities. Gabdulhakov claims that, nevertheless, academic debate describes digital vigilantism as a spontaneous phenomenon, whereas in Russia it is an institutionalized, highly organized and systematic practice $[\ldots]$. There is intricate dynamics as, on one hand, digital vigilantes respond to "dysfunctions" of state actors by taking justice into their own hands, thus stressing the impotence of state bodies. On the other hand, some vigilante groups in Russia receive presidential grants to support their activities and enjoy formal and informal endorsements from the highest authority. ${ }^{35}$

However, because many vigilantes act anonymously in the virtual world, it is impossible or at least very difficult to punish those whose actions actually deserve punishment. Thus, the tables turn, and now the other side feels that the legal system and the state cannot protect and defend them against inadequate or essentially unfair shaming acts. In this case, DV may serve "as means for small independent groups to exercise social power and control over marginalized and underrepresented groups [...] and has the capacity of web-distributed visual imagery to sustain a new kind of sadistic hegemony. [...] Circulation of the digital-networked images concomitantly perpetuates and motivates unjust and undemocratic desires." 36 Therefore, DV could serve not only to empower citizens but also as an antidemocratic mechanism for coercion of raw power, ${ }^{37}$ and it would serve as a normalisation practice, which could be harmful. Moreover, they not only "use digital tools not only to gather evidence or to publicise the identity of an alleged offender, but also to make a profit." 38 The profit from the act complicates the phenomena because yet again it questions the motivation of such behaviours.

One of the main differences between digital and traditional vigilantism is that DV is implemented by using technological tools. And the tool level is very important here, because when we understand how the new technologies are created and how the perception of human is changed by using them, only then could we better understand DV. In his famous article, Martin Heidegger

${ }^{35}$ R. Gabdulhakov, "Citizen-Led Justice in Post-Communist Russia: From Comrades' Courts to Dotcomrade Vigilantism," Surveillance \& Society 16, no. 3 (2018): 314-31.

${ }^{36}$ KASRA, "Vigilantism, Public Shaming," 173.

${ }^{37}$ R. Gabdulhakov, "In the Bullseye of Vigilantes: Mediated Vulnerabilities of Kyrgyz Labour Migrants in Russia," Media and Communication 7, no. 2 (2019): 230-41.

${ }^{38}$ G. Favarel-Garrigues, "Digital Vigilantism and Anti-Paedophile Activism in Russia. Between Civic Involvement in Law Enforcement, Moral Policing and Business Venture," Global Crime (October 21, 2019): 1-21. 
claims that "technology is not equivalent to the essence of technology." 39 The key is to understand that technology cannot be perceived merely as a neutral tool because then it would appear that this tool can be completely controlled by people. We cannot control the technologies we have created that does not mean that they can act on their own, but it is impossible to control them and know how they will be used in reality (e.g. nuclear power and the atomic bomb, Facebook and Cambridge Analytica, etc.).

\section{SWARMING CHANGES ACTING: POLITICS IN THE E-SOCIETY}

In his book "Consuming Life," Bauman puts forward the concept of swarms. According to Bauman, the swarm changes the group and the community, people gather only driven by certain ideas, interests, desires or activities, but these gatherings only last as long as their desired action continues. There is no continuity - one can belong to several swarms at one time, assemble, disperse and gather again, there is almost no commitment and responsibility. ${ }^{40}$ Bauman's concept of the swarm can be better understood by analysing DV.

Let us now quote the definition suggested by David Trottier: "Digital vigilantism is a process where citizens are collectively offended by other citizens' activity, and coordinate (spontaneously and autonomously mobilising) retaliation on mobile devices and social platforms. These offensive acts are typically not meant to generate large-scale recognition. Therefore, the targets of DV are initially unaware of the conflict in which they have been enrolled (emphases mine). ${ }^{" 41}$ In the following paragraphs I will try to explain all the features of DV as the better way to understand the concept of the swarm.

DV is temporary but it is a process rather than a single act, although the contribution of different people varies greatly. At the first stage, someone brings attention to a wrongful behaviour, and then the same person or someone else who is individually affected by that behaviour and who has the necessary IT (i.e. can access relevant data) proceeds to share such information. It is important to understand that the end result is never the result of just one

\footnotetext{
${ }^{39}$ M. Heidegger, The Question Concerning Technology and Other Essays (New York: Harper \& Row, 1977), 287.

${ }^{40}$ Bauman, Consuming Life, 76-77.

41 Trottier, "Digital Vigilantism as Weaponisation," 55-72.
} 
person's efforts - one person has found one piece of information, someone else has shared a link leading to relevant data, another person has published CCTV records, and someone else has viewed them, and so on. At a later phase, which actually takes place parallel to the first stage, data is shared - either exposing inappropriate behaviour or publishing the wrongdoer's personal information. The last stage involves a reaction, which happens in reality rather than in the virtual space. People suffer repercussions: they get fired, condemned by others, they may be fined or even go to prison.

While developing the concept of swarms, Bauman stresses that "swarms are not teams; they know nothing of the division of labour. They are [...] no more than the 'sum of their parts', or rather aggregates of self-propelled units, united solely [...] by 'mechanical solidarity', manifested in the replication of similar patterns of conduct and by moving in a similar direction. They can be visualized best as Warhol's endlessly copied images with no original, or with an original discarded after use and impossible to trace and retrieve." 42

According to the picture drawn by Bauman, a swarm starts to work when each of its members continuously repeats the same action, ${ }^{43}$ tweeting and retweeting or re-sharing. And most importantly, each action is done individually, without coordination.

Still, the case of DV raises some doubts concerning Bauman's ideas - he claims that there are no specialists in a swarm, they are all "jacks-of-alltrades" ${ }^{44}$ and no one assists each other. It is important to understand that DV does not really work as a traditional team, but the division of labour exists, however, it happens completely by accident, without assigning anyone with any tasks. Nevertheless, the case of DV shows that sometimes people act by supplementing each other's weaknesses or lack of resources - if one hacker cannot decode all data, he just uploads whatever he has and this unprocessed data is intercepted by someone else to complete the unfinished task, as if compensating for the previous hacker's drawbacks.

Postmodernism "does not mean that the 'normal', weekday conduct of the individuals has become random, un-patterned and uncoordinated. It only means that the non-randomness, regularity and coordination of individually undertaken actions can be, and are as a rule, attained by other means than the

\footnotetext{
42 Bauman, Consuming Life, 76-77.

${ }^{43}$ Ibid., 77.

${ }^{44}$ Ibid., 77.
} 
solid-modern expedients and stratagems of enforcement." 45 According to Bauman, discipline and punishment are no longer enough, other mechanisms are at work.

By using the term biopower, Foucault essentially states that traditional politics are changing and are being replaced by a completely different system, with no single clear centre, no clear leader - a divisive micro-policy that lives in local contexts and creates certain identities. ${ }^{46}$ In a swarm, every command from above is superfluous. After all, swarms are not superior; the current direction of their flight only puts some of the dynamics of a selfpropelled vehicle into the positions of leaders to be followed, which they occupy temporarily, and which change unpredictably. "As self-assurance and the sentiment of security go, the miraculously coordinated movements of a swarm are the next best substitute for the authority of group leaders, and no less effective. ${ }^{\prime 47}$ The sense of trust and security, that magically coordinates the movement of the swarm, is the best and equally as effective substitute for the authority of the group leaders." ${ }^{48}$ It is quite obvious that there are no distinct leaders in DV processes - every stimulus to take action seems exaggerated because the process is either happening or not. The most interesting part is that it is never possible to guess which wrongful behaviour will trigger such a severe reaction as it happens spontaneously every time, it accelerates remarkably quickly and crashes when the general interest dissipates.

\section{WHY AND HOW IS DIGITAL VIGILANTISM A POLITICAL ACT?}

It is becoming clearer that postmodern technology and life have shifted from ideas of modern unification towards the individualistic no-pill-foreverybody perspective. ${ }^{49}$ There is less and less need for traditional collective forms of being/acting/participating (political parties, communities, stable groups, etc.). Therefore, swarms, members of which are connected by weak links, may change the group and community. Some specific issue or interest

\footnotetext{
${ }^{45}$ BaUman, Consuming Life, 75-78.

${ }^{46}$ M. Foucault, The History of Sexuality, vol. 1, An Introduction (New York: Vintage, 1990), 135-45.

${ }^{47}$ Bauman, Consuming Life, 76-77.

${ }^{48}$ Bauman, Consuming Life, 75-78.

${ }^{49}$ A. DEmEntaviČIENĖ, "Kaip naujosios technologijos nulemia politinio veiksmo suvokimą: Digital Vigilantism atvejis?" Politologija 95, no. 3 (2019): 33-55.
} 
holds them together for an extremely short period (in comparison with communities). Swarms gather, scatter, and gather again, from one occasion to another, every time inevitably for a different reason, and are attracted by changeable aims.$^{50}$ However, swarms can be remarkably effective.

The act of vigilance always has been and still is politically driven, and this is digital vigilantism's basic similarity with conventional vigilantism. Politics of this act can be viewed from two aspects: (a) in principle as related to the state, law, bureaucracy, etc., and (b) as the preservation and consolidation of moral norms.

Moreover, it is important to understand that a DV act is based on the idea that the "vigilantes" are doing the things they do because they must bring morality and justice back to the world. ${ }^{51}$ And not just any morality, but an extremely simplified, "crystal clear," black-or-white concept of morality that makes it easy to categorize people into good-doers and wrongdoers. Through acts of DV, the vigilantes seek purity and clarity in morality (including the fight with bad protocol, hate speech, racism, sexism, terrorism, etc.). Regardless of the ideological reasons behind DV attempts (even aimed either against racism or a possible terrorist attack), it usually violates individual privacy, is not based on the innocent-until-proven-guilty principle, and does not attempt to look at the whole picture but rather at just one post, one photograph, or one video. In the view of vigilantes, it is obvious that the truth is "always on their side" and there is no reason to try to understand somebody from the "wrong-doers" side. Someone who suggests taking into account the arguments of "the dark side" could be regarded as a new target for DV.

In most cases it can be said that: "while lacking state authorization, vigilante groups do not perceive their actions as over-riding or transgressing the legal order but construct themselves as self-anointed guardians rescuing national sovereignty, citizenship and the law's moral sanctity, from cultural elites, moneyed interests, inept bureaucrats and a sclerotic state." 52 The vigilantes always perceive their actions as protecting, rescuing some sort of segment of society, or an idea, a moral outlook that are being stigmatized. In almost all cases, the action is presented as inevitable, obviously requiring the intervention of "ordinary" people — otherwise it will remain unresolved,

\footnotetext{
${ }^{50}$ E. PAleSe, "Zygmunt Bauman. Individual and Society in the Liquid Modernity," SpringerPlus 2, no. 1 (2013): 191.

${ }^{51}$ KASRA, "Vigilantism, Public Shaming," 172-88.

52 J. P. WALSH in: http://reframe.sussex.ac.uk/activistmedia/2016/04/digital-vigilantism-as-criticalreinforcement-of-law-and-order/, 2016.
} 
neglected, unnoticed. Such negative emphasis on impartiality and non-interference is characteristic of both conventional and digital vigilance.

Digital vigilantism, as we have discussed above, has a complex relationship with the establishment. However, the notion of thinking against elite is visible in many of the acts. This problem connects us with the discussions of the post truth and populism, because they all are supported by the lack of trust. Digital vigilantes do not believe that institutions are interested and capable of managing, sustaining and fully implementing the laws and morality norms. If fake news or, more broadly, post-truth narratives question and distrust institutions like universities, bureaucracy or science itself, the DV questions and distrusts the justice system.

In his "History of Sexuality", vol. 1, "The Will to Knowledge," Foucault claims that a very important consequence of the biopower is that norms or the acts of the normalisation are starting to overpower the justice, or the power of law. In my opinion, DV cases are an extreme example of this change. In these cases, the protection from the law that the suspect is not guilty until the trail says opposite is no longer valid; the norm implementing through the gun of the visibility changes it. Targets become "guilty no matter what the trail will say after years of the investigation." And sometimes they are guilty forever without almost any way of changing the status.

When the system is changed and biopower is operating, "government is everywhere" - it no longer has a definite core or a subject that both creates it and is responsible for it. The government does not occupy a clear position in society, leaving an imitation in its place - that is, governments, states and politicians who seemingly do politics still exist, however this just disguises the real position of the government, which is impossible to trace. It hides in everyday life and takes root as biopower through various microprocesses and new mechanisms of control: "[...] I do not mean to say that the law fades into the background or that the institutions of justice tend to disappear, but rather that the law operates more and more as a norm, and that the judicial institution is increasingly incorporated into a continuum of apparatuses (medical, administrative, and so on) whose functions are for the most part regulatory. A normalizing society is the historical outcome of a technology of power centered on life. We have entered a phase of juridical regression in comparison with the pre-seventeenth-century societies." ${ }^{, 53}$

Most importantly, regardless of the processes in reality, condemnation whether fair or unfair - occurs in the virtual world, as if each person indi-

${ }^{53}$ Foucault, The History of Sexuality, 144. 
vidually decides if there was a violation, a threat to the state, morality, public order, etc. According to Foucault, power is established not through the main arteries but through small capillaries, ${ }^{54}$ i.e., various expert systems are spread across all sections of the population, and biopower is spreading through them, governments are no longer competent institutions, decisions are taken in hospitals, laboratories, schools, not just in the parliament.

Another remarkable aspect of the manifestation of biopower is that it is becoming less and less possible to pinpoint what non-political life is, to distinguish between what is private and what is public, and also what belongs to the state and what is social. "Vigilantism is typically understood as extrastate, popular and extra-legal, yet it takes on 'state-like performances such as security enforcement' along with 'a perpetual renegotiation of the boundaries between state and society'." ${ }^{55}$ Along with what is private and public, Facebook merges all different worlds of citizens: colleagues, friends, family, classmates and bosses. ${ }^{56}$ This is one of the reasons why actions are so easily transposed from one context to another. This way, someone who misbehaved - say, yelled at a child in the park - may be dismissed from work the following day, for an act that is not actually related to this person's direct duties. The shaming campaign can be so massive that the employer simply does not want to be associated with that person, although if he simply found out about this incident privately, perhaps he would judge that employee personally, but his or her dismissal could not be justified. If there is a complete refusal to establish the boundaries of what is private and what is public, it is a dangerous moment, because then everything can be public and privacy in general disappears.

Therefore, the consequences for those who have experienced mass condemnation are often quite tough not only in the virtual world, but also in the real world: loss of employment, reputation, expulsion from university, imprisonment and the like. However, in practice, nobody takes responsibility for shaming campaigns. It precisely gets distributed among all the swarm members, who, surprisingly, can quickly forget or ignore their participation in any action. "In the case of human feelings and thoughts, the comfort of flying in a swarm derives from having security in numbers: a belief that the direction of flight must have been properly chosen since an impressively

\footnotetext{
${ }^{54}$ Ibid., $135-45$.

55 TROTTIER, "Digital Vigilantism as Weaponisation," 63.

${ }^{56}$ D. Trottier, Social Media as Surveillance: Rethinking Visibility in a Converging World (New York: Routledge, 2016), 1-7.
} 
large swarm is following it, a supposition that so many feeling, thinking and freely choosing human beings could not be simultaneously fooled." ${ }^{57}$ Just like in the conversation mentioned above, people do not think of re-sharing or re-tweeting as a substantial action, since so many people have done it before them - they do not feel responsible for the information that they share, even if it later turns out to be fake news.

Nevertheless, although the phenomenon of DV is not getting much attention from the field of political science or political philosophy, it provides us with some insights about the current changes in understanding of politics and the concept of what is "political." It invites us to reconsider the idea of swarms put forward by Bauman. While, at first glance, DV looks like an example of spontaneous groupings appearing in the (digital) social realm, it also points towards the potential of individuals randomly managing to divide responsibilities and functions, as opposed to Bauman's vision of "jacks-ofall-trades." It brings us to the conclusion that solid-modern expedients and stratagems of enforcement are no longer the central techniques for enforcement not only in the society (as it has a need of vigilantes outside of typical institutions) but also in specific groups (swarms). Accepting Foucault's ideas will allow us to see that contemporary digitalized/virtualized politics are dependent as much (if not even more) on omni-optical (peers in society judging and separating each other) and decentralized techniques, where responsibility is also dispersed, instead of traditional panoptical approaches, more characteristic of the 18th and 19th centuries, as described by Foucault. All this makes DV an interesting case because of its different approach to how politics, as a certain manipulation of power, and its relations are transformed. It also gives us an opportunity to think about the conceptualization of a different, transformed kind of politics for the digital age.

\section{CONCLUSIONS}

The discussion presented in this article is aimed at conceptualizing and elucidating the transformation of acts deemed "political" in the age of digital media and virtualized politics as such. The transformation of the phenomenon of vigilantism into a vast array of different digital activities (hacktivism, scam baiting, and cyber-stings among many others) under the conceptual umbrella of digital vigilantism is just one of many examples, which also

\footnotetext{
${ }^{57}$ Ibid., 77.
} 
once again proves that in the age of digital media and politics leaves students and researchers of politics with an expanded field of opportunities in terms of political activism. Consequently, this realization should also point towards the necessity to understand these new forms of political activism in the world.

This realization alone, however, is not enough. The call for understanding these new phenomena also requires that we find the ways and tools with which we could evaluate, research and understand these new ways of operating in the world. While the more traditional approaches to researching political processes, the logic of political acts, and the nature and dynamic of power relations are still useful in providing a foundation for this research, the technology-driven nature of new developments discussed in this article also underlines the need to reconsider these theories in light of what may be deemed as digital politics in the age of New Media in e-Society.

The realization and reconceptualization of the tools that researchers have should also be guided by much broader questions of how technological advances nowadays affect political acts, political attitudes, notions of participation and the concept of politics as such. Are we on the verge of a new breed of technology-driven politics? How should this new type of politics be treated, and, in case of its corrosive effects, controlled? Both questions, which are also tied to exploring technology-driven changes to our individual and collective identities, as well as social relations to each other are of utmost importance when theorizing and conceptualizing the notion of politics for today. This paper should be seen as one of many attempts to get closer to answering these questions.

The case of digital vigilantism discussed in this article allows us to ask questions about the contradictions of the umbrella-like phenomenon of DV, which are closely intertwined with questions about relation between digital technologies and open democratic politics as such. First and foremost, it raises questions about the ratio of empowerment as opposed to promotion of anti-democratic values using opportunities and tools for freedom and empowerment that digital technologies allow individuals today. Secondly, DV also allows us to ask about citizens ability to really enforce and distinguish between acts of anti-corruption versus acts of propaganda, related to the emotionally driven exposure of alleged "deep state" corruption and coverups and similar processes that often have no connection to factual reality whatsoever. Furthermore, it makes us ask questions about the balance of security in relation to discipline and control which the guarantee of security 
my bring - where will the balance be located? Which is more important security or freedom? Last, but not least, the classic question of security vs. freedom brings us to the paradox of surveillance vs. empowerment (or, sousveillance in certain theories). Do digital politics ultimately empower citizens more than ever, or is it just a smoke screen for even more expansive surveillance and dataveillance techniques, molding and shaping individual and collective identities without the realization of the subject?

All the questions above are, obviously, related to the much broader existential questions related to the effect that technology has on our (political) lives. How will our politics, and ultimately our very lives will look like in the age of virtualization and digitalization, when the lines between virtual and real fictions begin to blur? Following Bauman's line of thinking we may submit to, in a way, pessimistic (and even fatalist) realization that with technological transformation our lives will further continue to lose stability, making our politics reactive in nature. What, then, happens to proactive, creative political acts, and consequently, individual autonomy and agency in this world? However, that is not the only way to think about the new processes. What if technological transformation of politics leads us to new forms of politics, new ways of perceiving morality, ethics, and law? This is a discussion yet to be opened fully for more in-depth research, but this article should help to expand its possibilities.

\section{BIBLIOGRAPHY}

ANDREws, Robert. "Baiters teach Scammers a Lesson." Wired, April 8, 2006. https://www.wired. com/2006/08/baiters-teach-scammers-a-lesson.

Balabanian, Norman. "On the Presumed Neutrality of Technology." IEEE Technology and Society Magazine 25, no. 4 (2006): 15-25.

Bauman, Zygmunt. Consuming Life. Cambridge: Polity Press, 2007.

BREY, Philip. "Philosophy of Technology after the Empirical Turn." Techné: Research in Philosophy and Technology 14, no.1 (2010): 36-48.

Cheong, Pauline H., and Jie Gong. "Cyber Vigilantism, Transmedia Collective Intelligence, and Civic Participation.” Chinese Journal of Communication 3, no. 4 (2010): 471-87.

Clune, Bronwen. "Digital Vigilantism Think Before Putting Pictures of Wrongdoing Online." The Guardian, November 29, 2013. https://www.theguardian.com/commentisfree/2013/nov/ 29/digital-vigilantism-think-before-pictures-of-wrongdoing-online.

DemEnTAVIČIENĖ, Augustè. "Kaip naujosios technologijos nulemia politinio veiksmo suvokimą: Digital Vigilantism atvejis?" Politologija 95, no. 3 (2019): 33-55. 
DenNIS, Kingsley. "Keeping a Close Watch - The Rise of Self-Surveillance and the Threat of Digital Exposure." The Sociological Review 56, no. 3 (2008): 347-57.

Favarel-Garrigues, Gilles. "Digital Vigilantism and Anti-Paedophile Activism in Russia. Between Civic Involvement in Law Enforcement, Moral Policing and Business Venture." Global Crime (October 21, 2019): 1-21. https://doi.org/10.1080/17440572.2019.1676 738.

FORTEY, Ian, "8 Awesome Cases of Internet Vigilantism." Cracked, March 23, 2009. http:// www.cracked.com/article_17170_8-awesome-cases-internet-vigilantism.html.

Foucault, Michel. The History of Sexuality. Vol. 1, An Introduction. New York: Vintage, 1990.

Fuchs, Christian. Social Media: A Critical Introduction, London: Sage, 2017.

Gabdulhakov, Rashid. "Citizen-Led Justice in Post-Communist Russia: From Comrades' Courts to Dotcomrade Vigilantism.” Surveillance \& Society 16, no. 3 (2018): 314-31.

GabdulhaKov, Rashid. "In the Bullseye of Vigilantes: Mediated Vulnerabilities of Kyrgyz Labour Migrants in Russia." Media and Communication 7, no. 2 (2019): 230-41.

Haraway, Donna J. Manifestly Haraway. Posthumanities 37. Minneapolis: University of Minnesota Press, 2016.

HeIdegger, Martin. The Question Concerning Technology and Other Essays, 287-317. New York: Harper \& Row, 1977.

HiLl, Colin. "How Digital Communities Cope: Cyber-vigilantism Following the Boston Marathon Bombings." The Yale Review of International Studies (April 2017). http://yris.yira. org/essays/2039.

Johnston, Les. "What is Vigilantism?" The British Journal of Criminology 36, vol. 2 (1996): 220-36.

KASRA, Mona. "Vigilantism, Public Shaming, and Social Media Hegemony: The Role of DigitalNetworked Images in Humiliation and Sociopolitical Control." The Communication Review 20, no. 3 (2017): 172-88.

KeY. "Sue Me If You Dare, My Dad Is Li Gang." Chinahush, October 21, 2010. http://www. chinahush.com/2010/10/21/sue-me-if-you-dare-my-dad-is-li-gang/.

KIngSLEY, Denis. "Keeping a Close Watch - the Rise of Self-surveillance and the Threat of Digital Exposure." The Sociological Review 56, no. 3 (2008): 347-57.

KudĚLKa, Miloš, Zdeněk Horák, Václav SnÁšEl, Pavel Krömer, Jan Platoš, and Ajith AвRAHAm. "Social and Swarm Aspects of Co-authorship Network." Logic Journal of the IGPL 20, no. 3 (2012): 634-43.

Kucera, Michal, and Miroslav Mares. "Vigilantism during Democratic Transition." Policing and Society 25, no. 2 (2015): 170-87.

KwONG, Henry, and Christian JACOB. "Evolutionary Exploration of Dynamic Swarm Behaviour." Paper presented at the 2003 Congress on Evolutionary Computation, Canberra, Australia, December 8-12, 2003. IEEE (May 24, 2004). doi:10.1109/CEC.2003.1299599.

Loveluck, Benjamin. "The Many Shades of Digital Vigilantism. A Typology of Online Selfjustice." Global Crime (June 4, 2019): 1-29. https://doi.org/10.1080/174440572.2019.1614444.

PAlese, Emma. "Zygmunt Bauman. Individual and Society in the Liquid Modernity." SpringerPlus 2, no. 1 (2013): 191. https://doi.org/10.1186/2193-1801-2-191.

Ronson, Jon. "Strange Answers to the Psychopath Test." TED, March 2012. https://www.ted. com/talks/jon_ronson_strange_answers_to_the_psychopath_test. 
SHARON, Tamar. "Self-tracking for Health and the Quantified Self: Re-articulating Autonomy, Solidarity, and Authenticity in an Age of Personalized Healthcare." Philosophy \& Technology 30, no. 1 (2017): 93-121.

Smallridge, Joshua, Philip Wagner, and Justin N. Crowl. "Understanding Cyber-Vigilantism: A Conceptual Framework." Journal of Theoretical \& Philosophical Criminology 8, no. 1 (2016): 57-70.

Smith, Gregory B. "Heidegger, Technology and Postmodernity." Social Science Journal 28 (1991): 369-89.

TANNER, Samuel, and Aurélie CAMPANA. "'Watchful citizens' and Digital Vigilantism: A Case Study of the Far Right in Quebec." Global Crime (April 26, 2019): 1-21. https://doi.org/ 10.1080/17440572.2019.1609177.

Trottier, Daniel. "Digital Vigilantism as Critical Reinforcement of Law and Order." Re.Framing Activism, April 6, 2016. http://reframe.sussex.ac.uk/activistmedia/2016/04/digital-vigilan tism-as-critical-reinforcement-of-law-and-order.

Trottier, Daniel. "Coming to Terms with Social Media Monitoring: Uptake and Early Assessment." Crime, Media, Culture 11, no. 3 (2015): 317-33.

Trottier, Daniel. "Digital Vigilantism as Weaponisation of Visibility." Philosophy \& Technology 30, no. 1 (2017): 55-72.

Trottier, Daniel. Social Media as Surveillance: Rethinking Visibility in a Converging World, 17. New York, Routledge, 2016.

VAN DiJcK, José. “'You have one identity': Performing the Self on Facebook and LinkedIn." Media, Culture \& Society 35, no. 2 (2013): 199-215.

\section{A POLITICAL ACT IN THE E-SOCIETY: DIGITAL VIGILANTISM AND SWARMS}

\section{Summary}

The main aim of this article is, by using the case of digital vigilantism, to analyze what new challenges could occur in the E-society and how understanding of the self and self-act is changing during the process when more and more new technologies are integrated in people's everyday life. The swarm is a metaphor which Zygmunt Bauman uses to show how the understanding of communities is changed in liquid modernity. Swarms are based on untied, uncontrolled, shortterm relationships between consumers/users to achieve some goals. Swarms could be massive in numbers and have a lot of power for a very short period. One of the examples could be digital vigilantism, which is an act of punishing certain citizens (they are believed to deserve punishment) by other Internet users. One example of DV would be to put personal information on display to spread shaming acts. The problem is that people are interested in some actions for a very short time, but the political act/change requires an active and stable effort. Despite the phenomenon of DV not getting much attention from the field of political science or political philosophy, it provides us with some insights about the current changes in our understanding of politics and the concept of what is "political" as well as inviting us to reconsider the idea of swarms as put forward by Bauman.

Key words: digital vigilantism; swarms; E-society; Bauman; social media. 


\section{AKT POLITYCZNY W E-SPOŁECZEŃSTWIE: ZJAWISKO CYFROWEJ STRAŻY OBYWATELSKIEJ I ROJE}

Głównym celem tej pracy jest przyjrzenie się nowym wyzwaniom, które mogą wystąpić w e-społeczeństwie, oraz temu jak zmienia się sposób postrzegania siebie jako osoby i indywidualnego aktu $w$ trakcie nieustannej integracji nowych technologii z życiem codziennym. Zygmunt Bauman używa metafory roju, aby przedstawić w jaki sposób pojęcie społeczeństwa zmienia się w płynnej rzeczywistości nowoczesnego świata. „Roje” istnieją dzięki niepowiązanym, nieskontrolowanym, krótkotrwałym relacjom nawiązywanym pomiędzy konsumentami/użytkownikami po to, aby osiągnąć wspólne cele. Roje mogą ogromne oraz posiadać znaczącą moc, jednak tylko przez krótki czas. Przykładem tego może być sprawiedliwość samodzielnie wymierzana w świecie cyfrowym celem ukarania niektórych obywateli (którzy przez innych użytkowników internetu są uważani za zasługujących na karę), na przykład udostępnianie informacji osobowych na forum publicznym, aby potępić dane zachowanie. Jednak problem polega na tym, że społeczeństwo nie jest zainteresowane takimi jednorazowymi akcjami, a akt lub przemiana polityczna wymaga aktywnego i trwałego wysiłku. Mimo że działania internetowej straży obywatelskiej nie budzą większego zainteresowania ze strony nauk politycznych lub filozofii politycznej, dostarczają wiedzy o zmieniającym się współcześnie rozumieniu świata polityki pojęciu tego, co jest „polityczne". Skłaniają nas także do zastanowieniem się nad ideą rojów w rozumieniu Zygmunta Baumana.

Słowa kluczowe: digital vigilantism; internetowa straż obywatelska; roje; e-społeczeństwo; Bauman; media społecznościowe. 